Asia Proceedings of Social Sciences

(APSS)

www.readersinsight.net/APSS

\title{
Leadership Initiative to Attain Business Sustainability: Reorienting Strategies to Meet the Needs of Globalization
}

\author{
Perwez Hashmi
}

PhD Scholar, Management Sciences, KASBIT

Pakistan

\section{Nayeem ul Hassan Ansari}

PhD Scholar, Management Sciences, KASBIT Pakistan

\section{Ahsanullah}

Supervisor, Management Sciences, KASBIT

$$
\text { Pakistan }
$$

*Corrosponding author's Email: perwez.hashmi@aku.edu

Peer-review under responsibility of $4^{\text {th }}$ Asia International Conference 2018 editorial board (http://www.utm.my/asia/our-team/) (C) 2018 Published by Readers Insight Publisher, lat 306 Savoy Residencia, Block 3 F11/1,44000 Islamabad. Pakistan, info@ readersinsight.net 


\section{Research High Iight s}

The research sought to identify the leadership initiative to attain business sustainability by integrating advance technology and capable human resources. While studying the performance of organizations in global needs, leads to creation of strong, skilled and competent leadership has ability to optimize measurable outcomes by using existing resources.

The objective is to create awareness across the industries for transformation of conventional and traditional practice to high fidelity technology and systems and training and development of human resource to meet fast growing challenges.

A quantitative technique was used to analyze the three factors leadership, technology and human resources skills are the mandatory strength for organizational effectiveness. A convenient sample was used to collect primary data through direct interview, The data enable to apply multiple regression models to be specified the correlation among the variables

The results reflected several modalities as leadership role to envision and adopt new and relevance technology to boost the outcomes and develop employees' capacity have positive relationship with firm performance. Recommendation was made to develop leadership profound skills and valuable insights regarding integration of new technology and enhance human capital, to achieve sustainable economic dynamism.

\section{Graphical A bstract}

Any figure that can reflect your research results (optional). If you do not have any picture please remove this section.

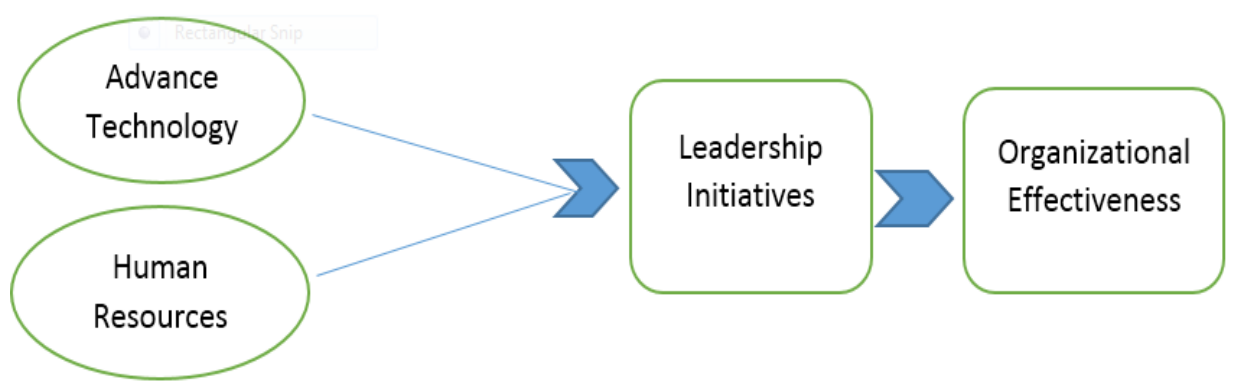




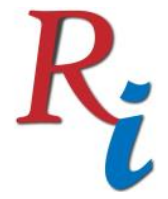

Asia Proceedings of Social Sciences

(APSS)

www.readersinsight.net/APSS

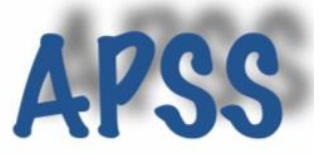

\section{Research Objectives}

The background and aim of the paper to identify top talented leadership and integrate strategies into the process to provide opportunity to keep them in continuous development practice to acquire competencies. The missing factor is that most of the organizations could not able to integrate leadership developing plan into their process and resulting organization pays huge loss due to unavailability of competent leaders who could take right decision in the contemporary rapid changing technological landscape. In the absence of leadership development programme organizations bear a greater loss due to inadequate policies initiatives and lack of appropriate technological changes into the systems.

The objective of the paper requires competent leadership with profound strength, visionary and adequate knowledge for the relevant industry. In the absence of high fidelity technology which is required to add values into the product, we may able to run an organization but could not able to make it sustainable in regards with its people, product, process and ultimately financially strengths.

Significance reveals that leadership and human resources are competent enough to foresee rapidly changing landscape of technological advancement, demand of the customer and awareness regarding values of the products and services rendering are the needs of leadership initiatives and adequate decision to develop relevant strategies

\section{Methodology}

Quantitative technic was used as methodology of the study to ascertain overall plan of the research, ways and means to be utilized and strategies taken to accomplish desired results. Selections of the variables are based on repeated used in the research papers to determine the leadership initiative and their strategies in organizational performance. The conceptual frame work of the thesis to determine both dependent and independent variable and their relationship to develop impact on organizational effectiveness were sought. Pilot testing and data reliability are the core functionality taken care for this study and obtained an authentic result. To find the relation a different approach and quantitative method of reviewing the structured data based on direct interview were used in the study 


\section{Results}

The result revealed that high quality leadership initiative especially to developing advance technological support in the process is the forefront to increase performance. The result shows that as the amount of skills and technology increase the external pressure increases to improve leadership competencies to provide tangible outcome for organizational effectiveness. While studying the core and overlapping relationship among all three independent variables reveals a positive relationship among themselves.

However, the organizational effectiveness are showing close and significant relationship 0.221 with the leadership initiative describing leaders must possess high level of conceptual skill to look into the future for taking decision to change in the policies and procedure. Interesting it is also noted that advance technology tend to relate closely to the leadership effectiveness and has a positive relation as such skills is required hands on and motor skill of the technology used in the organization, their process and changing pattern needed. The positive correlation between human skills and organizational effectiveness further confirms the integration between these two variables.

\section{Findings}

The technological landscape has been changing so rapidly that firms are finding it difficult to keep pace with ever-changing market situations. Leaders are of the view that advance technologies play the role of a business partner and a strategic enabler and in such a competitive environment, competent human capital has assumed considerable significance in achieving market niche. Leaders are endeavoring how to develop and leverage this human capital in support of business needs. To find a different measurable outcome requires changes in the process and adapt integrative approach for measuring performance. Results of the analysis reveals and demonstrated strong association with dependent and independent variables and identified that leadership competencies in taking initiative to adopt new technology and develop policies to implement is the forefront and spearhead process to achieve sustainability of the organizations. It is recommended that changing into the systems and process ultimately, enhances working process, structure of the organization, decision making and can effect on organizational sustainability. 
www.readersinsight.net/APSS

\section{References}

Rusliza Yahaya, Fawzy Ebrahim, (2016) "Leadership styles and organizational commitment:

literature review", Journal of Management Development, Vol. 35 Issue: 2, pp.190-216, doi: 10.1108/JMD-01-2015-0004

Mahesh Subramonya, Jesse Segersb, Clint Chadwickc, Aarti Shyamsunderd (2017) " Leadership development practice bundles and organizational performance: The mediating role of human capital and social capital, Journal of Business Research-120-129.

Pimentel JRC, Kuntz JR, and Elenkov Detelin (2010) "Ethical Decision-making: an integrative model for business practice" journal: European Business Review, volume 22 Number 04, pp: 359-376.

Martha C Andrews, Thomas Baker, Tammy g. Hunt (2011), "Values and person-organization fit, does moral intensity strengthen outcomes"? Journal, Leadership \& Organizational Development Journal, Volum \# 32, number -01.

Govan Svensson, (2011), “A conceptual framework of corporate and business ethics across organization structure process and performance. Journal the learning organization, volume \# 18, number 0969-6474 